\title{
8 Becoming a teacher in the 21st century
}

\author{
Teacher education reform in Sweden, \\ Germany, and England
}

\author{
Lindsey Waine and Susanne Wiborg
}

The first two decades of this century witnessed unprecedented reforms to teacher education in Germany, England, and Sweden. Already prior to the new millennium, we saw the dawn of a new era for education and teacher training. Countries were plunged into a new and different international environment of globalisation, technological innovation, and intense economic competition. In the realm of education, countries saw human capital as crucial to their ability to compete in the new 'knowledge economy', and to demand from their education systems much higher levels of academic achievement. At around the same time, countries were faced with the so-called 'crisis of the welfare state', the onset of fiscal austerity, demands for government efficiency, and rising disaffection with centralised, bureaucratic modes of governance. New reforms were implemented that placed a premium on accountability, monitoring competence, and professionalisation sharp departures from the institutional past. As this new era took hold, the creation of egalitarian education structures was no longer enough and the emphasis was now on academic excellence, which the existing institutions were not specifically designed to provide. Governments thus focused more strongly on the preparation of teachers in this changed environment.

At the start of this century, with the publication of the first PISA results by the Organization for Economic Cooperation and Development (OECD), there were stark criticisms of teacher education internationally (OECD, 2014). In 2013, Andreas Schleicher, the OECD's Director for Education and Skills, asserted, 'the quality of an education system cannot exceed the quality of its teachers'. This empirical statement has been a key influence on a multitude of policies espousing 'best practices' in education worldwide. With teacher quality deemed the most influential factor for student achievement, governments have embarked on reforming their teacher education systems. In the developing international arena, and with the competition engendered by studies such as PISA and TALIS, the OECD's survey of teachers, policymakers have increasingly looked beyond their borders for inspiration and models. Policies to reform pre-service teacher education aim to control the outcomes of the training that teachers receive, most often through the introduction of competences or standards they must achieve in order to qualify. These standards combine the knowledge and practical skills needed to 
be a competent classroom practitioner; however, this paradigm shift towards an evidence-based assessment of teaching has clear implications for the level of professional autonomy with which future teachers are able to practise.

The key questions to be addressed in this chapter are: how have governments in Germany, England, and Sweden sought to have greater control of pre-service teacher education, and what effect has the resulting increase in accountability had on teachers' practice in terms of professional autonomy? The concepts of professional accountability (being responsible for one's practice to others) and professional autonomy (freedom and self-regulation of one's practice) are not mutually exclusive. In answering these questions, we will focus primarily on reforms to teacher education curricula, particularly the role and weighting of theory and practice, and the assessment of student teachers' classroom practice by rubrics of standards.

\section{Germany: from enduring stability to radical reform}

Prior to 2000, education in Germany was characterised by an enduring stability that had weathered the storms of the two world wars, the construction and demolition of the Berlin Wall, and the reunification of the country in 1990. The strong federal structure established following the Second World War saw education decision-making devolved to the individual federal states, which had autonomy over the school curriculum and the recruitment and appointment of teachers. The historical legacy of a selective secondary education sector, with three school types (tripartite), was fiercely defended, and Germany was proud of its strong academic traditions. The universities in each federal state enjoyed considerable autonomy in terms of both the academic curriculum and organisational management, and within each university, the teacher education curriculum was determined by the academics involved, resulting in a huge diversity across Germany. In common with its Nordic neighbours, teacher education was founded on the ideology of Bildung, a holistic approach to learning that placed importance on epistemic knowledge (Männikko-Barbutiu, Rorrison and Zeng, 2011).

Having rested on its academic laurels for so long, Germany was entirely unprepared for the humiliation that ensued after the OECD published the results of its first PISA study in 2000. As Meyer and Benavot (2013, p. 2) put it, 'Germany had always tacitly assumed that they led the world in education'. The 'PISA shock', a term frequently used by the German media, prompted closer scrutiny of teachers' work and the effectiveness of pre-service teacher education in preparing teachers for the challenges of increasingly diverse and inclusive classrooms. The past two decades have witnessed unprecedented levels of reform to schools, the school curriculum, and teacher education. Wiseman (2013) suggests that PISA 2000 exerted a form of 'soft power', with Germany's performance impelling policymakers to implement reforms aimed at improving quality and equity in schools. Teacher education became the 'driving force' of delivering these improvements and was charged with producing a new generation of teachers who would be trained to achieve these policy aims (Blömeke, 2006). 


\section{The dual organisation of teacher education}

Teacher education in Germany is divided between two distinct locations and phases. The first phase is the responsibility of higher education institutions - universities and Pädagogische Hochschulen ${ }^{1}$ - and culminates in the First State Examination. This phase is strongly academic and comprises a study of two subject disciplines - didactic methods and education science. The opportunity for student teachers to connect theory with the practice of teaching presents itself in education science. However, historically, academics in this field did not consider it their role to make this connection and education science long remained a 'largely selfcentred and field-specific orientation' until the 1990s (Schriewer, 2017, p. 85). The second phase takes place within designated training centres operated by the federal state education authority and run by experienced teachers (Studienseminar) and ends with the Second State Examination. Student teachers spend most of their time in a designated school honing practical classroom skills and attend the centres regularly for further study. The focus of the training sessions is also practice-related and may have little connection to the academic content of the first phase. Thus, the first phase prioritises academic learning, rooted in the theoretical, and the second, the practical classroom skills to be assimilated before qualifying as a teacher.

Prior to 2000, the first, university-based, phase of teacher education could last for six or seven years and the second phase, further two years. Aside from the long duration of the study, there were two key criticisms of this system. First, the distinct roles of the two institutions involved meant that there was little or no communication between them. The academic side was heavily theoretical and had established itself as quite separate from the practical: would-be teachers had little opportunity to spend time in schools observing teachers and beginning to develop their classroom skills. It was therefore little wonder that student teachers struggled to see a clear connection between theory and practice. Second, the structure of the university programme meant that an early career choice was forced upon future teachers since they were required to complete courses in didactics and education science early in their undergraduate studies. These two factors go some way to explaining the high dropout rates among student teachers until the last decade (Mause, 2013).

\section{Teacher education and the catalysts for structural reform}

Implemented concurrently with the PISA-driven reforms, the objectives of the Bologna Declaration of 1999 to create a unified European Higher Education Area provided an additional challenge for Germany, whose universities had enjoyed considerable autonomy and to whom the notion of delineated undergraduate and postgraduate study was anathema (Keuffer, 2010). Nevertheless, a lack of cohesion within the teacher education curriculum and poor communication between the different university departments responsible for student teachers had resulted in an overloaded system and extended duration of study (Ostinelli, 2009). The universities had resisted calls from some academics within their ranks to create a more integrated, cohesive teacher education curriculum (Oelkers, 2004), and perpetuated a system that Blömeke calls 'organised irresponsibility' (2006, p. 321). 
However, the requirements of Bologna meant the introduction of a streamlined, modular structure to university programmes and specific timeframes for the completion of undergraduate and postgraduate studies. A transition period of 10 years was agreed by the education ministers of the federal states, at the end of which the duration of the first phase would be reduced to five years. Today, the teacher education curriculum comprises mostly compulsory modules, with the undergraduate years focused on in-depth study of the subject disciplines, and education science and subject didactics are concentrated in the postgraduate years.

In the wake of PISA and Bologna, there has also been an increase in the importance placed on education research. The Federal Ministry of Education and Research (Bundesministerium für Bildung und Forschung; BMBF) was established in 2004 and has produced several reports on teacher education which have identified key areas for improvement. The most relevant for the current discussion is how teacher education is structured during the university phase and how to optimise the connection between theory and practice (BMBF, 2019). The focal points of the study were the need to promote effective self-reflection in student teachers, an evaluation of the new, staged approach to practicums and the preparation of student teachers for the inclusive classroom.

\section{The current teacher education curriculum}

Questions concerning the balance between the theoretical and the practical in university-based teacher education continue to prompt debate inside and outside the academic community. In most federal states in Germany, teachers have civil servant status, ratified by two State Examinations. As such, they are afforded considerable professional autonomy in their work, based on the expectation that they will exercise sound professional judgement, founded on knowledge and understanding of learners, the learning process and the educational context. This professional knowledge has traditionally been constructed from theories taught as part of the academic curriculum; however, recent reforms have placed far greater emphasis on the length and timetabling of the practicum during the first phase, offering one strategy for mitigating the high dropout rate in teacher education by strengthening the link to the professional role. Previously, the prioritisation of theoretical knowledge over the practicum had frequently led to a so-called 'practice shock' experienced by student teachers starting the second, post-university phase, which was mostly spent teaching in one school (Sander, 1995; Jones, 2000; Terhart, 2004).

Recent reforms have seen progress in creating a better balance between theory and practice in two respects. First, in all federal states, there have been changes to the length and type of the practical elements of the curriculum. The main practicum has been extended to a full semester and there are additional practical experiences during the undergraduate phase, with the specific aim of preventing a forced early career decision. In some states, for example, North-Rhine Westphalia, an Eignungspraktikum (suitability practicum) is to be completed before studies begin, and is designed to allow future student teachers to reflect on their motivation for becoming a teacher and confirm their career decision. The Orientierungspraktikum (orientation practicum) lasts approximately one month and provides an experience 
of the classroom environment through the observations of experienced teachers. Finally, some states also have a Berufsfeldpraktikum (professional practicum), in which students spend time with other education professionals who work with teachers, such as social workers, youth workers, or special educational needs teachers. The semester-long practicum has been moved to the master's phase and is accompanied by practicum modules that encourage greater reflection and self-evaluation in student teachers. Whilst this has generally been acknowledged as a positive step, recent literature has highlighted that seeing the extended practicum duration as the 'holy grail' of teacher education neglects the fact that there is no clear conception of what role the practicum actually plays, or its purpose within university teacher education, and to date, there has been very little empirical research on its effects on student teachers' conceptions of teaching (Rheinländer and Scholl, 2020).

Second, some progress has been made in improving continuity and communication between the two phases of teacher education, in the form of the newly created Zentren für Lehrerbildung (Centres for Teacher Education). These are dedicated university departments, whose purpose is to facilitate communication between university faculties and the state education authority organising the second phase. All federal states have now introduced such centres, although the nomenclature varies, and they operate through working groups that foster communication between the different institutional partners.

\section{Teacher education and the professionalisation agenda}

The pressure to achieve economic competitiveness, coupled with the quality of education coming under the spotlight of international comparative studies, has prompted the German government to increase the monitoring of teacher quality by introducing competence-based teachers' standards, which were agreed by education ministers from the 16 federal states in 2004. These standards are organised as a hierarchy to be achieved at each stage of teacher education, beginning with the university practicums and continuing into the second phase. Student teachers are assessed against these standards and, although each standard is linked to the relevant underpinning theories, there is inevitably a normative aspect to the notion of competence. The need to be held accountable to a rubric of standards has clear ramifications for the professional autonomy of future teachers if it results in fewer opportunities to experiment with different approaches, rather than developing an individual teaching style that will take them forward after qualification.

In 2008, centralised control was further increased with the implementation of a standardised teacher education curriculum for education science. The emphasis on practical competence and tighter central control forms part of the professionalisation agenda, the objective of which is a greater orientation of teacher education towards the profession. Kotthoff and Terhart (2017, p. 7) suggest that this will prove to be: 'a challenge to the self-image of German universities, which are traditionally focused on the transmission of academic subject knowledge ("science") rather than the direct and practical preparation for a professional career'. It remains to be seen whether the recent reforms result in more cohesive preparation for student teachers, and whether recruitment to the profession will improve as a result. With 
the majority of federal states abandoning the tripartite secondary sector in favour of two secondary school types and a greater diversity in pupils attending grammar schools, the need for an integrated teacher education curriculum that produces new teachers with sound professional knowledge and confidence in classroom skills is more pressing than ever.

\section{England: from halcyon times to audit culture}

In stark contrast to the stability and reform reticence that had characterised Germany, pre-service teacher education in England has been the subject of continuous reform since the 1980s and has developed into a 'fast-changing, fragmented and diversifying system with multiple providers and diverse routes into teaching existing alongside and sometimes interwoven with traditional study at degree or postgraduate level' (Feiman-Nemser and Ben-Peretz, 2017, p. 14). The halcyon decades from the 1950 s to the 1970 s had culminated in a graduate-only teaching profession, with teacher education the domain of higher education. The universities offered a theoretical curriculum which embraced the social sciences and shared much with the German model: it comprised pedagogical studies with related social sciences, and subject-focused teaching methods, which provided a theoretical underpinning for the practicum. The economic recession of the late 1970s and a move towards accountability-oriented models of government refocused attention on education and the quality of teachers and, since the 1980s, successive governments of both political persuasions have exercised ever tighter control over teacher education and teachers themselves.

The golden era referred to above notwithstanding, pre-service teacher education in England has been unable to shake off the deeply entrenched historical legacy of the belief that teaching is a 'craft' that can best be learnt 'on the job', without recourse to theories or academic study. In his seminal work Does education matter? (1985), Brian Simon seeks to provide answers for the lack of pedagogy or 'the science of teaching'. He attributes this omission to the powerful historical influence of the prestigious public schools, which dismissed the notion of teachers requiring professional training and asserted that with a good subject degree from a top university, teaching could simply be learnt through experience, or at least with the support of an experienced teacher as a mentor. This apprenticeship model of teacher education, which prioritises practical skills and is deeply sceptical of education theory, has prevailed, and ultimately paved the way for a model of teacher education that is entirely school-based.

This persistent anti-pedagogism, and the ideology of teaching as a craft, has resulted in a fragmented and complex system of teacher education, divided between higher education institutions and schools. Demographic changes in the 1990s that increased the primary school population and, concurrently, shrinking school rolls in the secondary sector, produced a shortfall in teachers. This created the necessary conditions for the introduction of school-based teacher education. The SchoolCentred Initial Teacher Training (SCITT) programme was established in 1995 and was replaced by School Direct in 2010. Since that time, the number of routes has increased further: currently, $45 \%$ of student teachers are registered for the 
university programme (PGCE) route, and $40 \%$ are on the non-remunerated school-based programme. ${ }^{2}$

\section{The current teacher education curriculum and its challenges}

The tensions between the theoretical and the practical elements of teacher education evident in both Germany and England are exerted in opposite directions. Whereas the prioritisation of theory in Germany has had implications for the role of the practicum, in England, the precedence given to the practicum has challenged the provision of theoretical content by universities. This emphasis on practical competence in the latter has meant that the university curriculum is constrained by the requirement for student teachers to complete a minimum of 120 days in the classroom, which is organised in two practicum schools. One outcome of this extended time in schools is that the teaching of theory is condensed into two intensive blocks, one at the start of the programme and one between the two practicum blocks. Academics in teacher education have naturally criticised this development as reductionist and argue that they have been forced to engage in: 'a major rethinking of course content, with less emphasis on learning theory and more on the necessity of preparing student teachers for "survival" in the classroom' (Brant and Vincent, 2017, p. 170). Ellis (2010) concurs and suggests that school-based routes are similarly reductive and often result in a linear experience for student teachers because acculturation in the host school means that they are more likely to accept its pedagogical practices and less likely to challenge them or experiment in their own practice. Although student teachers on school-based routes are taught together periodically in geographical clusters, the emphasis remains on classroom skills, rather than theoretical content.

Student teachers negotiating this complex array of teacher education options cite diverse motives for selecting one or the other of the routes into teaching. Those choosing to study at a university consider the academic environment and theoretical content of the programme to be advantageous in terms of gaining an understanding of the wider issues of education and the range of pedagogic approaches they can apply to their practice. The generous bursary offered to students in shortage areas, for example, STEM subjects, is a further incentive. A proportion of student teachers opting for the School Direct route are remunerated whilst training and this, together with greater control over the geographical location of the placement school, is a strong motivating factor, and an important consideration for those with dependants.

For all routes, students seem to be clear about making the right decision; however, a small-scale study by Maguire and George (2017) found that whilst the majority of student teachers believed it was important to maintain both university and school-based teacher education options, each group voiced strong views. Student teachers on School Direct programmes said they regretted only gaining experience in one school and were worried that they would be unable to explore different pedagogic approaches if these did not comply with their placement school's ethos and working practice. University-based student teachers said the 
reputation of the university was a factor in their selection, and believed the academic route was more likely to produce outstanding teachers.

\section{Teacher education and the professionalisation agenda}

The reform-heavy culture that has existed in England since the 1980s and the drive to improve the quality of education have resulted in an audit culture in which schools, teachers, and teacher educators are subject to close central monitoring and target-setting. This quality control structure has meant that international comparative studies such as PISA have had a more limited influence on the reform agenda since 2000 in England, relative to their neighbours in Europe (Grek, 2009). Similarly, the pre-existing structure of undergraduate and postgraduate qualifications in English universities has meant that the Bologna Declaration did not require the sweeping structural changes seen in German universities. Internally, the increasing control of successive governments over pre-service teacher education has produced a blend of deregulation in terms of the diversification of teacher education providers and centralised auditing of their provision. Thus, two decades before Germany introduced national teachers' standards, a compliance culture was well-established in England, with both institutions of teacher education and their staff held accountable through the Office for Standards in Education (Ofsted), whose brief is to ensure that teachers and student teachers meet professional standards.

Competence-based assessment and the requirement to evidence a set of standards, together with the marginalisation of academic theory, have attracted criticism from teacher educators (Ellis, 2010; Gilroy, 2014; Wilkins, 2011). Gilroy suggests that the success of those who provide teacher education now rests on their willingness to produce compliant teachers. Going a step further, Wilkins believes that the professional standards go beyond the assessment of classroom skills and strike at the very identity of teachers by judging 'their values and attitudes' (ibid, p.395). To an extent, it could be said that the current teachers' standards and the close scrutiny by external agencies like Ofsted encourage teacher educators to 'teach to the test' rather than offering student teachers an expansive curriculum that strengthens their knowledge and understanding and develops the professional judgement associated with autonomous practitioners. Ball expresses concern over the performative approach to teachers' work: 'inside classrooms teachers are [now] caught between the imperatives of prescription and the disciplines of performance. Their practice is both "steered" and "rowed"” (2003, p. 163).

This certainly seems contradictory to the aspiration expressed by the New Labour government, and explicitly or implicitly endorsed by its successors, that: 'We hope that teaching will emerge as the most admired profession of the 21st century and the one that young people are keenest to join' (DfES, 2002, p. 134). The shortfall in recruitment to teacher education in recent years, together with the high rate of attrition, suggest otherwise. The strong focus on evidencing competences during training, and the demands of the national curriculum and its prescriptive targets, may produce new teachers for whom the notion of professional autonomy remains elusive. 


\section{Sweden: from collective endeavours to individualised practice}

Since the early 1990s, Swedish governments have reformed the entire education system, including teacher education, to enhance the performance of pupils and teachers alike. Over the years, a standardised curriculum, national tests, a new grading system, and school inspection to oversee standards of learning were introduced (Wiborg, 2013). Teachers too were targeted with reforms that aimed at increasing pupil attainment and improving professional teaching skills. These reforms were similar to those introduced in England and elsewhere in Europe, but the impact was more dramatic in Sweden because the starting point was remarkably different. Sweden had a larger welfare state, a stronger social democracy, and a comprehensive school system with mixed ability classes in which teachers worked as a single professional corps. There was no professional hierarchy across the different education sectors; teachers were all subject to the same working conditions and were placed on the same salary scale. Primary school teachers received the same final salary as upper-secondary school teachers (Strath, 2004; Wiborg, 2017). Yet, interestingly, Swedish changes to primary/lower-secondary education and pre-service teacher education were faster and more all-encompassing than in other countries pursuing similar reforms. During the 1990s and 2000s, reforms strengthened both the subject-specific components of teacher training at the expense of education theory (pedagogy) and enhanced practical teaching skills Lilja (2014). There was thus a switch in the emphasis from education theory to academic school subjects in school-based settings. Training became more school-focused and less theorydriven. A new subject, education science, replaced the existing subject of pedagogy, aiming to strengthen evidence-based teacher training and practice. All these changes were enshrined in a flow of policy documents that became increasingly detailed and prescriptive of the training of teachers.

\section{The current teacher education curriculum: Top of the Class}

The reform initiatives culminated with the introduction, in 2010, of Top of the Class, a new teacher education programme (Government Bill 2009/10:89). This replaced the integrated programme (successive bachelor's and master's degrees in education) with four new professional degrees, targeting the key education sectors: preschool, primary school, lower- and upper-secondary schools, and vocational education. In all cases, the curriculum now comprises both theory and practice and includes a compulsory core of education science worth 60 credits (equivalent to a full year of study), subject studies (subject knowledge and didactics), and practical teaching through a school placement. Subject studies for secondary school teaching require three subjects for lower-secondary teachers and two for upper-secondary.

Programme content is regulated by a single System of Qualification, which contains the learning outcomes that student teachers must meet to pass the final exam, and regulates the content of education science and the subject areas taught. Another measure to enhance the standards was the introduction of 'senior subject teachers'. A teacher who has a doctoral degree and demonstrated excellent quality 
of teaching over a period of at least four years is to be appointed a senior subject teacher. Furthermore, in 2012, a system of teacher and preschool teacher registration came into force. To be qualified to teach in schools, a teacher is required to be registered and qualified for specific subjects and school years. Registration is also required for a teacher to be able to grade students and to act as a mentor for new teachers.

\section{Work conditions, performance pay, and professionalisation}

The reforms in pre-service teacher education since the early 1990s and culminating in the 2010 Top of the Class legislation have had serious ramifications for teachers' working conditions, remuneration, and construction of professionalisation. The introduction of clearer employment regulations for permanent teaching staff was accompanied by a system of performance-related pay. Teachers are now put on an individual pay scheme, first introduced in 1995, which gives municipalities the tools for recruiting and rewarding teachers. The rationale behind the pay scheme was that teacher salaries should be linked to clearly defined performance objectives, which in turn would serve as an instrument for retaining effective teachers. Most crucial was the decision that pay should be based on pupil results, although this was not implemented as originally intended: today, some of the pay is dependent on 'softer criteria' such as the contribution teachers make to creating a positive learning environment, instilling democratic values and tolerance, motivating pupils and boosting their self-esteem, cooperating with other teachers, their desire to pursue professional development, etc. (Strath, 2004).

The intention of these recent professionalisation reforms is to provide each category of teacher with the specialised knowledge relevant to the age group they teach. Rather than forming a professional identity on the basis of the teaching corps as a whole, professionalisation is linked to the specialised knowledge and expertise involved in only one sector of the school system. To enhance these skills and develop a professional identity on the basis of teacher categories, the government gave a boost to teachers by providing programmes that offer university-based training for those without a teaching qualification in the subject or age group they teach. The first phase of the programme (Lärarlyftet I: 2011-2017) enrolled 30,000 teachers. The second phase, launched in 2012 (Lärarlyftet II: 2012-2018), provided training courses for those who wished to become special-needs teachers (Lindstrom and Beach, 2015; Sjöberg, 2019). The reforms of teacher education have become focused on individual student teachers and their achievements, and the construction of a teacher identity that is organised around clear performance goals.

Thus, teacher professionalisation has developed from a collective endeavour to teach in common schools for all to a more individualised practice. Teachers today have a high degree of professional autonomy and are typically organised in small teams which share responsibility for organising their work and are required to contribute to school strategies to achieve national student learning goals. The importance of individualised teaching practices and the needs of pupils have increased considerably. According to Giota and Emanuelsson (2018), traditional class work has been largely phased out in favour of individualised self-regulatory 
teaching methods and flexible learning strategies. Pupils are given further opportunities to develop their ability to work independently and to take more responsibility for their own learning.

\section{Conclusion}

The reforms to teacher education in Germany, England, and Sweden since 2000 have demanded radical changes in the structure of the curriculum and the assessment of student teachers. There have been compromises to the freedom traditionally enjoyed by student teachers as they contend with more mandatory modules, increased practicum time, and tougher assessment of their practical skills through rubrics of standards to be achieved throughout their studies. In Germany and England, the introduction of competence-based assessment through prescribed standards has been motivated by the belief that tighter centralised control and accountability will assure improvements to teaching quality, pupil attainment and ultimately, economic competitiveness. 'Quality' is itself a contestable concept, and how or whether it can be measured using rubrics of standards or competences has been a subject of debate among academics who argue that the complex and uncertain nature of the classroom environment cannot be reduced to skills-focused statements or that personal characteristics of the teacher cannot be expressed as a 'standard' (Männikko-Barbutiu, Rorrison and Zeng, 2011; Mattsson et al., 2011).

In Germany, more practical experiences for student teachers through school placements have reduced dropout rates, and Centres for Teacher Education have improved communication among all those involved in teacher preparation. Earlier practical experiences coupled with the shortage of teachers, which is now at a critical level, has meant that most states have shortened the second phase of teacher education to 18 months or a year. Where the average age for starting a first teaching post in the late 1990s was 32 (Kotthoff and Terhart, 2017), today's student teachers may well enter employment four years earlier. The introduction of teachers' standards in 2004 has endeavoured to connect skills statements with the corresponding theory, suggesting that, despite some rebalancing in the theory and practice elements of the teacher education curriculum, theoretical knowledge is still considered essential to professionalisation and enables teachers, once qualified, to work autonomously and exercise professional judgement.

Teacher education in England has been the victim of cultural scripts that consider the profession as a craft that can be acquired without recourse to theory in the academic sense. A deep-rooted scepticism of the teaching of education theories on university courses, together with a belief that an apprenticeship model of teacher education is the most effective, have resulted in successive governments promoting school-based routes into teaching. The primacy of practice now means that the teacher education curriculum centres around practicums that occupy about 24 weeks of the training year. Whatever their chosen route, student teachers today have to contend not only with the demands of heterogeneous classrooms and challenging behaviour, but also the pressures of an intensive year of relentless planning and preparation, reading and written assignments, and the need to prove themselves to be 'competent' by meeting prescribed professional standards. 


\section{4}

Lindsey Waine and Susanne Wiborg

Increased centralised auditing of both new and experienced teachers throughout their career has eroded the autonomy they used to enjoy in the past. The struggle to retain new teachers beyond five years suggests that further reforms are needed to address this.

In Sweden, radical changes to teacher education meant that specific subject expertise was upgraded at the expense of education theory, pedagogy, and placement in schools, which had given student teachers a deeper experience of what it means to work as a professional teacher. The subject of pedagogy was replaced with education sciences, placing teacher education on a stronger, evidence-based footing, including classroom management. These performance-oriented teacher education reforms replaced previous reforms that had sought to create a common professional identity with integrated teacher education for all categories of teachers, the same working conditions, and salaries based on seniority. Since 2011, a new system has been in existence, with different specialist pathways to becoming a teacher, a body of expert knowledge, and individualised pay schemes.

The pre-service teacher education curriculum in all three countries has been re-balanced at different times to prioritise the acquisition of practical classroom skills and to produce teachers who are better equipped to deal with the challenges of today's diverse and inclusive classrooms. In Germany and England, this has resulted in professionalisation reforms that express the teacher's role in terms of standards to be evidenced. Sweden has adopted a more radical approach, replacing a unitary qualification model with one that embraces a number of different models, but without recourse to rubrics of standards. The guiding idea behind this reform was that specialisation would unleash the expertise of different teacher categories, leading to targeted, individualised teaching methods and, ultimately, driving up standards. In all three countries, pressures to achieve academic excellence have led to dramatic reforms in recent decades. Yet, as this chapter has shown, how the reforms manifested, and the pathways to academic excellence they laid out, varied greatly, with differing impacts on teacher autonomy and accountability.

\section{Notes}

1 These specialist education universities have been preserved in the state of BadenWürttemberg. In all the other federal states, they were integrated into the universities from the 1970s.

2 Department for Education (November 2020): Initial Teacher Training (ITT) Census for the academic year 2019-2020, England.

\section{References}

Ball, S.J. (2003) 'The teacher's soul and the terrors of performativity', Journal of Education Policy, 18(2), pp. 215-228. doi: 10.1080/0268093022000043065.

Blömeke, S. (2006) 'Globalization and educational reform in German teacher education', International Journal of Educational Research, 45, pp.315-324.doi:10.1016/j.ijer.2007.02.009.

Brant, J. and Vincent, K. (2017) 'Teacher education in England: professional preparation in times of change', in Trippestad, T.A., Swennen, A. and Werler, T. (eds.) The struggle for teacher education: international perspectives on government and reforms. London; New York: Bloomsbury. 
Bundesministerium für Bildung und Forschung (BMBF) (2019) Verzahnung von Theorie und Praxis im Lehramtsstudium.

Department for Education and Skills (DfES) (2002) Time for standards: reforming the school workforce. London: DfES Publications.

Ellis, V. (2010) 'Impoverishing experience: the problem of teacher education in England', Journal of Education for Teaching, 36(1), pp. 105-120. doi: 10.1080/02607470903462230.

Feiman-Nemser, S. and Ben-Peretz, M. (2017) Getting the teachers we need: international perspectives on teacher education. Lanham, Maryland: Rowman and Littlefield.

Gilroy, P. (2014) 'Policy interventions in teacher education: sharing the English experience', Journal of Education for Teaching, 40(5), pp. 622-632. doi: 10.1080/02607476.2014.957996.

Giota, J. and Emanuelsson, I. (2018) 'Individualized teaching practices in the Swedish comprehensive school from 1980 to 2014 in relation to education reforms and curricula goals', Nordic Journal of Studies in Educational Policy, 4(3), pp. 144-155. doi: 10.1080/ 20020317.2018.1541397.

Grek, S. (2009) 'Governing by numbers: the PISA 'effect' in Europe', Journal of Education Policy, 24(1), pp. 23-37. doi: 10.1080/02680930802412669.

Jones, M. (2000) 'Becoming a secondary teacher in Germany: a trainee perspective on recent developments in initial teacher training in Germany', European Journal of Teacher Education, 23(1), pp. 65-76. doi: 10.1080/026197600411634.

Keuffer, J. (2010) 'Reform der Lehrerbildung und kein Ende? Eine Standortbestimmuung', Erziehungswissenschaft, 21, p. 40.

Kotthoff, H.-G. and Terhart, E. (2017) 'Teacher education in Germany: traditional structure, strengths and weaknesses, current reforms', Scuola Democratica, 3, pp. 1-10. doi: $10.12828 / 75802$.

Lilja, P. (2014) The politics of teacher professionalims: intrapreofessional boundary work in Swedish teacher union policy. Policy Futures in Education, 12(4), pp. 55-512.

Lindstrom, M.N. and Beach, D. (2015) Changes in teacher education in Sweden in the neoliberal education age: toward an occupation in itself or a profession for itself? Education Inquiry, 6(3), pp. 241-258.

Maguire, M. and George, R. (2017) 'Reforming teacher education in England: locating the "policy problem"”, in Trippestad, T.A., Swennen, A. and Werler, T. (eds.) The struggle for teacher education: international perspectives on government and reforms. London; New York: Bloomsbury.

Männikko-Barbutiu, S., Rorrison, D. and Zeng, L. (2011) 'Memorable encounters', in Mattsson, M., Eiertsen, T.U. and Rorrison, D. (eds.) A practicum turn in teacher education. Rotterdam: Sense Publishers.

Mattsson, M., Eiertsen, T.U. and Rorrison, D. (2011) A practicum turn in teacher education. Rotterdam: Sense Publishers.

Mause, K. (2013) 'With Bologna in mind and the sword in the hand: the German bachelor/ master reform reconsidered', Higher Education Policy, 26, pp. 325-347. doi: 10.1057/ hep.2013.4.

Meyer, H.-D. and Benavot, A. (eds.) (2013) PISA, power and policy: the emergence of global educational governance. Didcot: Symposium Books.

OECD (2014). TALIS 2013 results: an international perspective on teaching and learning. OECD Publishing, Paris. Available from: http://www.oecd.org/education/school/talis-2013results.htm.

Oelkers, J. (2004) 'Problems in teacher training: what innovations are possible?', European Education, 36(1), pp. 50-70. doi: 10.1080/10564934.2004.11042346. 
Ostinelli, G. (2009) 'Teacher education in Italy, Germany, England, Sweden and Finland', European Journal of Education, 44(2), pp. 291-308. doi: 10.1111/j.1465-3435. 2009.01383.x.

Rheinländer, K. and Scholl, D. (eds.) (2020) Verlängerte Praxisphasen in der Lehrerbildung. Konzeptionelle und empirische Aspekte der Relationierung von Theorie und Praxis. Bad Heilbrunn: Verlag Julius Klinkhardt.

Sander, T. (1995) 'Quality improvement and austerity measures in teacher education: lessons from Germany', European Journal of Teacher Education, 18(1), pp. 97-113.

Schriewer, J. (2017) 'Between the philosophy of self-cultivation and empirical research: educational studies in Germany', in Whitty, G. and Furlong, J. (eds.) Knowledge and the study of education: an international exploration. Didcot: Symposium Books.

Simon, B. (1985) Does education matter? London: Lawrence and Wishart Ltd.

Sjöberg, L. (2019) 'The Swedish primary teacher education programme: at the crossroads between two education programme traditions', Education Inquiry, 10(2), pp. 116-133. doi: 10.1080/20004508.2018.1492845.

Strath, A. (2004) Teacher policy reforms in Sweden. The case of individualised pay. Paris: International Institute for Educational Planning, UNESCO.

Terhart, E. (2004) 'Teacher training reform', Journal of European Education, 36(1), pp. 29-49. doi: 10.1080/10564934.2004.11042347.

Wiborg, S. (2013) 'Neo-liberalism and universal state education: the cases of Denmark, Norway and Sweden 1980-2011', Comparative Education, 48(2), pp. 420-423. doi: 10.1080/03050068.2012.700436.

Wiborg, S. (2017) 'Teacher unions in the Nordic countries: solidarity and the politics of self-interest', in Moe, T.M. and Wiborg, S. (eds.) Comparative politics of education. Teachers unions and education systems around the world. Cambridge: Cambridge University Press.

Wilkins, C. (2011) 'Professionalism and the post-performative teacher: new teachers reflect on autonomy and accountability in the English school system', Professional Development in Education, 37(3), pp. 389-409. doi: 10.1080/19415257.2010.514204.

Wiseman, A.W. (2013) 'Policy responses to PISA in comparative perspective', in Meyer, H.D. and Benavot, A. (eds.) PISA, power and policy: the emergence of global educational governance. Didcot: Symposium Books. 